\title{
Penentuan Konsep Pengembangan Kawasan Pedesaan di Kecamatan Tulung, Kabupaten Klaten
}

\section{Determine the Concept of Rural Area Development in Tulung District, Klaten Regency}

\author{
Estar Putra Akbar ${ }^{\mathrm{a}}$, Grandy Loranessa Wungo ${ }^{\mathrm{b}} *$ \\ ${ }^{a}$ Politeknik Negeri Pontianak, Pontianak, Indonesia \\ ${ }^{b}$ Universitas Diponegoro, Semarang, Indonesia
}

\begin{abstract}
Menurut RTRW Kecamatan Tulung menjadi kawasan pertanian dan kawasan industri. Permukiman yang tumbuh di Kecamatan Tulung cenderung memusat di berbagai titik yang terdapat pusat aktivitas seperti industri. Permukiman di Kecamatan Tulung berkembang secara organik atau unplanned. Letak Kecamatan Tulung cukup strategis yaitu berada diantara Kabupaten Klaten dan Kabupaten Boyolali serta akses jalan kolektor Jatinom-Boyolali yang menghubungkan Kabupaten Boyolali dan Kabupaten Klaten juga membuat Kecamatan Tulung mudah dijangkau. Hal ini menyebabkan Kecamatan Tulung menjadi kawasan hunian yang ideal yang berdampak pada bertambahnya luas lahan permukiman tanpa ada control dari pemerintah. Konsep Eco Industrial Village diharapkan mampu menjawab masalah yang ada di Kecamatan Tulung. Metode pengumpulan data diperoleh melalui survei primer dan sekunder. Survei primer dilakukan dengan terjun langsung ke lapangan untuk melakukan observasi lapangan, wawancara, serta pemetaan denga Teknik analisis deskriptif. Tujuan penelitian ini dibagi dalam beberapa sasaran: pertama, penentuan konsep pengembangan wilayah. Kedua, melakukan pemetaan zonasi kawasan sesuai dengan konsep.
\end{abstract}

Kata Kunci: Pedesaan; Eco-village; Zoning

\begin{abstract}
According to the RTRW, Tulung District has become an agricultural and industrial area. The settlements that grow in Tulung Subdistrict tend to focus at various points where there are centers of activity such as industry. Settlements in Tulung Subdistrict developed organically or unplanned. The location of Tulung Subdistrict is quite strategic, which is located between Klaten Regency and Boyolali Regency and Jatinom-Boyolali collector access road that connects Boyolali Regency and Klaten Regency also makes Tulung Subdistrict easily accessible. This causes Tulung Subdistrict to become an ideal residential area which has an impact on increasing the area of residential land without any control from the government. The concept of Eco Industrial Village is expected to be able to answer the problems in Tulung Subdistrict. Data collection methods were obtained through primary and secondary surveys. The primary survey was conducted by going directly to the field to conduct field observations, interviews, and mapping with descriptive analysis techniques. The purpose of this study is divided into several objectives: first, determining the concept of regional development. Second, mapping the zoning of the area in accordance with the concept.
\end{abstract}

Keyword: Rural; Eco-village; Zoning

\section{Pendahuluan}

Kecamatan Tulung merupakan salah satu kecamatan yang terletak di Kabupaten Klaten,

\footnotetext{
* Grandy Loranessa Wungo

E-mail address: grandywungo@ live.undip.ac.id
} 
Provinsi Jawa Tengah. Berdasarkan RTRW Kabupaten Klaten, Kecamatan Tulung ditujukan sebagai kawasan pertanian dan kawasan industry mie soon. Permukiman yang tumbuh di Kecamatan Tulung cenderung memusat di berbagai titik yang terdapat pusat aktivitas seperti industri. Permukiman di Kecamatan Tulung berkembang secara organik atau unplanned.

Letak Kecamatan Tulung cukup strategis yaitu berada diantara Kabupaten Klaten dan Kabupaten Boyolali serta akses jalan kolektor Jatinom-Boyolali yang menghubungkan Kabupaten Boyolali dan Kabupaten Klaten juga membuat Kecamatan Tulung mudah dijangkau. Hal ini menyebaban Kecamatan Tulung menjadi kawasan hunian yang ideal sehingga mengakibatkan bertambahnya luas lahan permukiman di Kecamatan Tulung.

Kawasan permukiman merupakan kawasan di luar kawasan lindung yang digunakan sebagai lingkungan tempat tinggal atau hunian masyarakat berada di wilayah perkotaan dan perdesaan (Koestoer, 1997). Setiap permukiman tentunya memerlukan perencanaan guna membentuk kondisi yang ideal di masa yang akan mendatang. Identifikasi terhadap potensi dan masalah serta hubungan dengan aktivitas yang ada pada suatu kawasan pemukiman perlu dilakukan dalam proses perencanaan suatu kawasan pemukiman. Setelah mengetahui potensi dan masalah pada suatu permukiman maka perencanaan yang akan dilakukan dapat memiliki arahan dan program yang jelas.

Perencanaan pada suatu kawasan permukiman diharapkan akan mendukung potensi serta mengatasi permasalahan yang ada. Perencanaan yang dilakukan tentunya juga akan menyesuaikan potensi dan masalah pada permukiman tersebut. Wilayah perencanaan pada studi ini adalah permukiman industri pati aren di Kecamatan Tulung dengan luas sebesar $101 \mathrm{Ha}$ dan mencakup Desa Tulung, Desa Pucang Miliran, dan Desa Daleman. Kecamatan Tulung memiliki potensi sebagai sentra industri pati aren. Hasil produksi dari pati aren tersebut sudah diekspor ke berbagai daerah seperti Lampung dan Yogyakarta. Industri mie soun juga berkembang di Kecamatan Tulung. Industri mie soun tersebut telah menjadi mata pencaharian utama bagi sebagian besar masyarakat di Kecamatan Tulung.

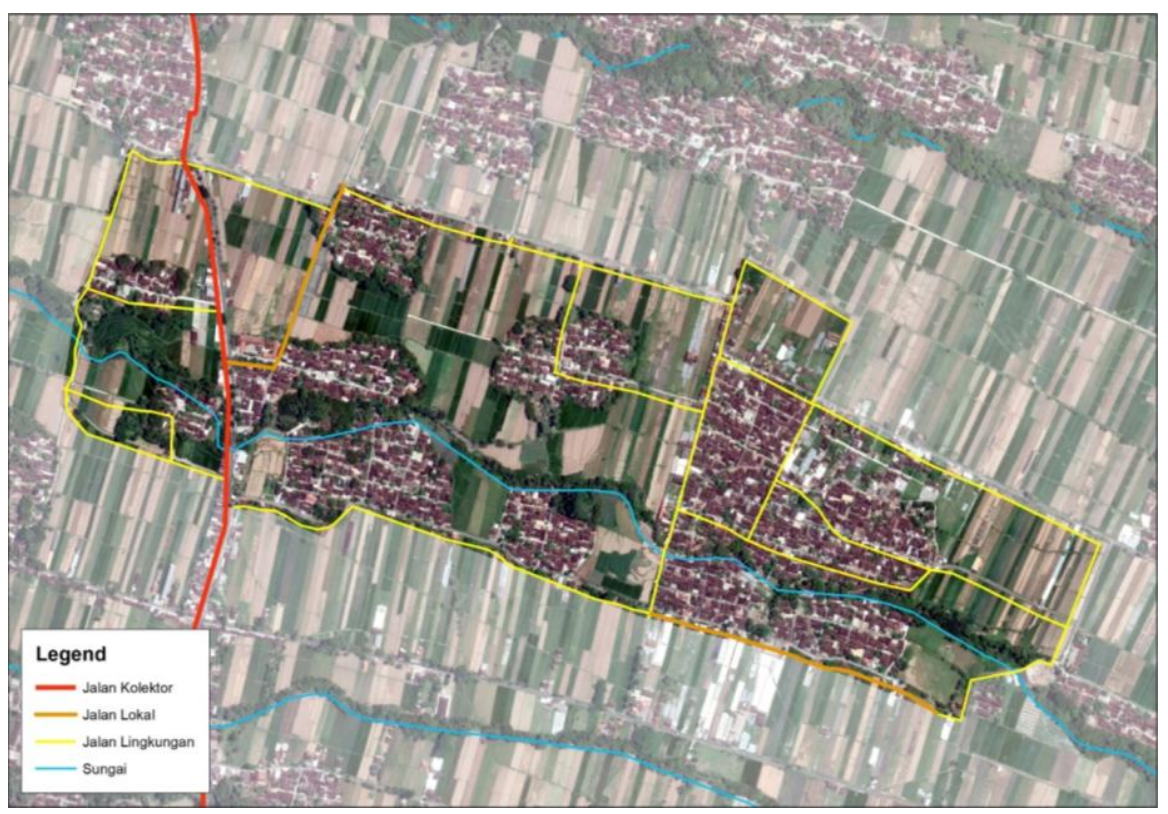

Gambar 1. Peta Wilayah Studi (Analisis Penulis, 2019)

Dibalik potensi yang dimiliki di wilayah perencanaan terdapat berbagai permasalahan. Permasalahan tersebut berupa pencemaran air dan udara yang diakibatkan oleh limbah pengolahan pati aren. Masalah lain yang muncul adalah masalah persampahan yakni belum adanya sistem persampahan dan kebiasaan buruk masyarakat yang membuang sampah ke sungai menjadi salah satu faktor munculnya permasalahan tersebut. Jalan rusak juga menjadi salah satu masalah yang muncul. Masalah jalan rusak tersebut diakibatkan oleh truk-truk pengangkut batang aren yang mengirimkan bahan produksi bagi industri tepung pati aren.

Potensi industri pati aren apabila direncanakan dengan baik akan mendukung kondisi perekonomian masyarakatnya. Perencanaan yang baik pula diharapkan masalah yang ada mampu teratasi. Potensi yang besar serta berbagai masalah yang timbul bersama potensi 
tersebut mendasari para peneliti untuk melakukan perencanaan dan sosialisasi pada wilayah tersebut. Berdasarkan potensi dan masalah yang ada maka disusun sebuah konsep perencanaan kawasan permukiman di pedesaan yang diharapkan mampu memaksimalkan potensi serta mengatasi masalah-masalah yang muncul. Hal tersebut memungkinkan kualitas hidup masyarakat di permukiman industri pati aren dapat menjadi lebih baik. Tujuan penelitian ini adalah untuk menentukan konsep dan zonasi kawasan perencanaan pemukiman industri pati aren yang sehat dan nyaman.

\section{Metode}

Metode pengumpulan data diperoleh melalui survei primer dan sekunder. Survei primer dilakukan dengan terjun langsung ke lapangan untuk melakukan observasi lapangan, wawancara, serta pemetaan. Observasi lapangan dilakukan dengan mengamati kondisi fisik maupun non fisik pada wilayah perencanaan. Wawancara dilakukan dengan mengajukan beberapa pertanyaan kepada beberapa masyarakat yang dijadikan sampel sebagai narasumber. Wawancara dilakukan dengan teknik snowball sampling kemudian untuk hasil analisis peneliti menggunakan teknik analisis deskriptif.

Daftar pertanyaan yang disiapkan sesuai dengan tujuan yang ingin dicapai dan kebutuhan pada TKD. Pemetaan dilakukan dengan penitikan lokasi fasilitas umum maupun fasilitas sosial di wilayah perencanaan. Pemetaan untuk mendapatkan titik-titik koordinat lokasi fasilitas dibantu dengan GPS. Titik-titik koordinat lokasi yang diperoleh lalu dikonversikan menjadi peta persebaran fasilitas dengan bantuan ArcGIS. Survei sekunder dilaksanakan dengan menelaah dokumen berupa buku, jurnal, artikel, maupun publikasi instansi di internet. Hasil analisis tapak kemudian di-overlay menggunakan ArcGIS untuk mendapatkan zonasi kawasan perencanaan.

\section{Kajian Literatur Konsep Eco-village}

Istilah Eco-village mulai diperkenalkan oleh Robert Gilman dalam suatu kegiatan di Denmark pada tahun 1991. Global Eco-Village Network pada tahun 2000 mengatakan bahwa eco-village adalah pilihan untuk mengubah disintegrasi antar budaya dan sosial, serta merupakan solusi dari berbagai permasalahan yang ada di bumi. Perhatikan tabel berikut.

Tabel 1. Definisi dan Prinsip Eco-village

\begin{tabular}{ll}
\hline & \multicolumn{1}{c}{ Eco-village } \\
\hline Definisi & Konsep yang mengedepankan aspek lingkungan seiring dengan perkembangan \\
& pembangunan perkotaan yang semakin pesat dengan memanfaatkan sumber daya \\
& yang ada secara baik dan efektif. \\
\hline Prinsip & - Menggunakan tanah atau lahan secara benar \\
& - Melakukan efisiensi terhadap sumber daya alam yang terbatas \\
& - Mengutamakan kesehatan manusia untuk pembangun dan pemilik \\
& - Menggunakan material lokal non-toxic untuk menunjang ekonomi lokal \\
& - Preservasi tumbuhan, hewan dan habitat alam \\
& - Mengurangi penggunan energi fosil dan memanen energi alam \\
&
\end{tabular}

Gilman (1991) dalam (Jackson, 1998) juga menetapkan bahwa eco-village yaitu pemukiman dengan fasilitas lengkap, di mana aktivitas manusia terorientasi dengan alam serta mendukung pembangunan yang sehat dan dapat dilanjutkan pada masa depan (pembangunan berkelanjutan). Adapun pengertian lain tentang eco-village yakni model permukiman berkelanjutan pada konteks kultural, spiritual, ekologis, dan ekonomi (Adalilar, Alkibay, \& Eser, 2015; Hall, 2015; Ristianti, 2016; Sherry, 2019). Sehingga eco-village menerapkan asas pelestarian fungsi lingkungan dalam mewujudkan pembangunan berkelanjutan, baik pelestarian fungsi pada komponen lingkungan (biotik, abiotik, maupun komponen sosial ekonomi dan budaya serta kesehatan masyarakat). Tujuan adanya eco-village adalah untuk menciptakan hidup yang berkelanjutan dan penghidupan yang baik (wellbeing) (Hall, 2015; Roysen \& Mertens, 2019). 


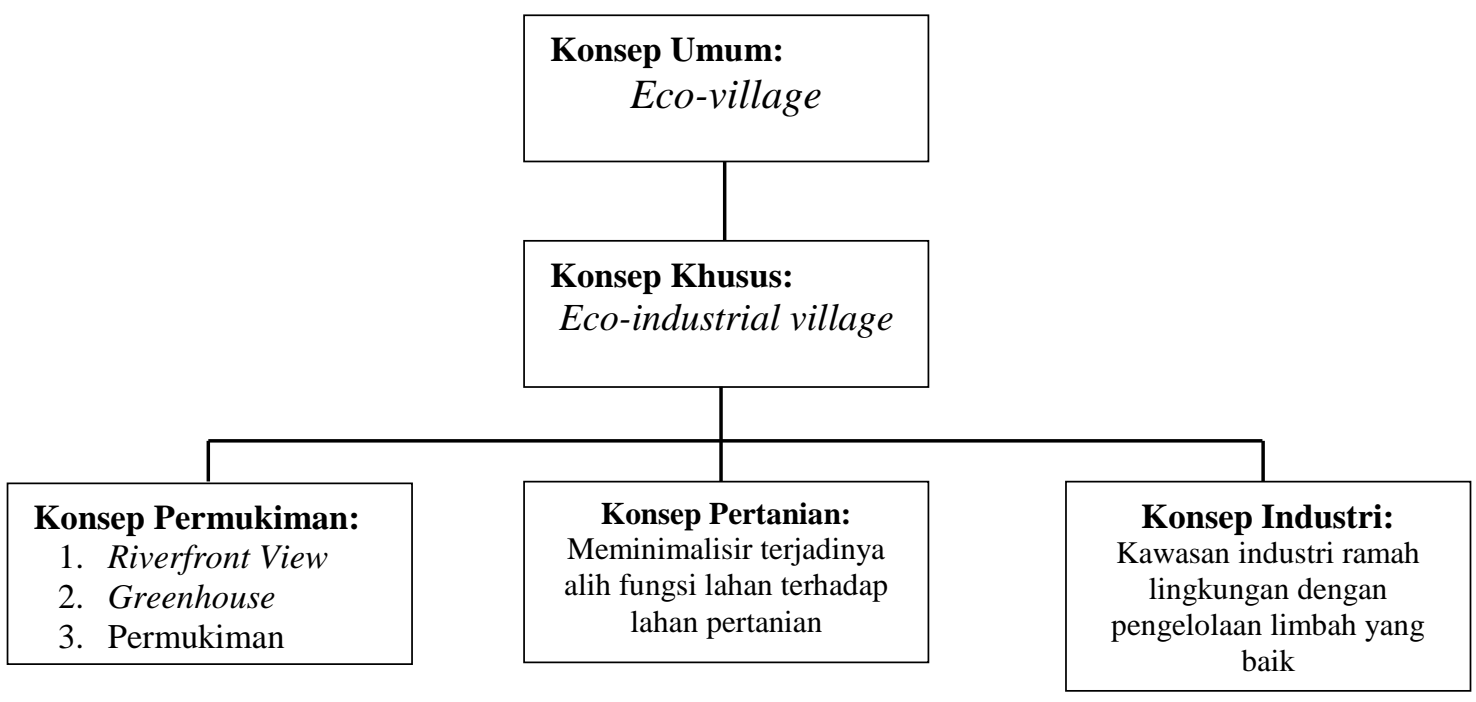

Gambar 2. Rincian Konsep (Analisis Penulis, 2019)

Eco-village merupakan konsep besar dari konsep Eco industrial village. Eco industrial village adalah konsep di mana pembangunan yang dilakukan dapat meminimalisir pencemaran terhadap lingkungan yang disebabkan oleh pabrik industrial yang tidak mengganggu aktivitas masyarakat, aliran sungai, dan persawahan. Tujuan utama dari konsep ini adalah untuk mengorganisir sistem industri sehingga industri tersebut bersifat ramah lingkungan dan berkesinambungan terhadap alam. Jika konsep tersebut diterapkan, maka kawasan industri dapat mengembangkan sistem pertukaran limbah yang dapat bermanfaat bagi lingkungan.

\section{Hasil dan Pembahasan}

Data dan informasi yang telah diperoleh dari kegiatan survei kemudian dianalisis sehingga didapatkan konsep pengembangan wilayah perencanaan. Konsep ini dikhususkan untuk perencanaan kawasan permukiman di wilayah perencanaan tersebut. Sebelum masuk pada penjelasan konsep pengembangan wilayah perencanaan, penting untuk memahami potensi serta masalah yang menjadi urgensi dilakukannya perencanaan.

\subsection{Potensi Wilayah Perencanaan}

Pada wilayah perencanaan terdapat beberapa potensi yang dapat dikembangkan yakni sebagai berikut.

1) Wilayah perencanaan memiliki topografi yang relatif datar / landai yakni 0\%-8\% sehingga cocok untuk aktivitas hunian, pertanian, industri, perdagangan jasa, dan aktivitas pendukung lainnya.

2) Wilayah perencanaan tidak termasuk kawasan rawan bencana seperti banjir dan longsor sehingga cocok untuk kawasan permukiman

3) Jenis tanah yang terdapat di wilayah perencanaan merupakan jenis tanah regosol (vulkanik) yang subur, cocok untuk kegiatan pertanian

4) Adanya akses jalan kolektor primer yang menghubungkan antara Kabupaten Boyolali dan Kabupaten Klaten sehingga memudahkan akes keluar masuk wilayah perencanaan yang berpengaruh terhadap kegiatan harian masyarakat khususnya perdagangan dan jasa serta industri

5) Terdapat sentra industri tepung aren dan mie soun yang berada di Desa Daleman dan Desa Pucang Miliran yang memberikan lapangan pekerjaan bagi masyarakat di wilayah perencanaan selain profesi sebagai petani dan buruh tani. Industri tersebut dapat berpotensi meningkatkan kesejahteraan masyarakatnya.

\subsection{Masalah Wilayah Perencanaan}

Selain potensi, terdapat pula beberapa permasalahan di wilayah perencanaan yang perlu untuk segera diselesaikan yakni sebagai berikut. 
1) Limbah hasil kegiatan industri tepung aren dan mie soun tidak terolah dengan baik dikarenakan tidak tersedianya tempat penampungan serta instalasi pengolahan limbah. Limbah cair yang dihasilkan dari kegiatan industri tersebut hanya dibuang ke saluran air di sekitar lokasi industri tanpa pengolahan terlebih dahulu. Limbah padat yang dihasilkan khususnya yang dihasilkan oleh industri tepung aren hanya diletakkan di sepanjang bahu jalan pada kawasan industri sehingga mengganggu estetika atau keindahan lingkungan di sekitar kawasan industri dan permukiman. Limbah-limbah tersebut baik cair maupun padat menguarkan bau tidak sedap sehingga cukup mengganggu aktivitas harian masyarakat yang bertempat tinggal di sekitar kawasan industri tersebut.

2) Orientasi bangunan-bangunan rumah pada kawasan permukiman eksisting tidak tertata sehingga pemanfaatan lahan untuk kawasan permukiman tidak maksimal

3) Terdapat beberapa jalan lokal dan lingkungan yang rusak sehingga cukup menghambat aksesibilitas di wilayah perencanaan

\subsection{Konsep Pengembangan Wilayah Perencanaan}

Kawasan permukiman di wilayah studi merupakan kawasan permukiman yang berdampingan dengan kawasan industri yang berpotensi menimbulkan potensi dan masalah. Terutama permasalahan yang berkaitan dengan lingkungan, seperti pencemaran limbah. Tetapi di sisi lain, industri yang terdapat di wilayah studi juga berpotensi untuk meningkatkan kesejahteraan masyarakat sekitarnya. Berdasarkan potensi, masalah, serta isu yang terdapat di wilayah perencanaan maka konsep pengembangan wilayah perencanaan yang sesuai adalah ecoindustrial village. Konsep eco-industrial village mengedepankan kawasan pemukiman yang nyaman dan sehat dengan kehadiran industri yang ramah lingkungan. Industri yang ramah lingkungan di sini mengartikan bahwa limbah yang dihasilkan dapat terolah dengan baik sebelum bertemu langsung dengan lingkungan alam. Limbah yang sudah terolah dengan baik tentunya tidak akan mencemari lingkungan alamnya. Lingkungan alam yang tidak tercemar dapat memberikan pengaruh yang baik bagi kawasan pemukiman serta kawasan pertaniannya. Pengaruh baik tersebut berupa kawasan pemukiman yang nyaman untuk ditinggali serta lahan persawahan yang tetap terjaga kondisinya.

Konsep eco-industrial village memfokuskan pada perencanaan kawasan permukiman yang sehat, aman, dan nyaman untuk ditinggali meskipun harus berdampingan dengan kawasan industri yang bising. Aktivitas utama yang terdapat di wilayah perencanaan yakni aktivitas pemukiman, pertanian, dan industri. Maka dari itu konsep eco-industrial village didesain untuk menunjang aktivitas utama maupun aktivitas penunjang di wilayah perencanaan. Konsep eco industrial village dirincikan lagi berdasarkan peruntukkan kebutuhan dari aktivitas penduduknya sebagai berikut:

\subsubsection{Konsep Permukiman}

Konsep permukiman pada wilayah perencanaan akan dibagi menjadi 3 yaitu:

\section{Riverfront view}

Konsep riverfront view adalah permukiman yang berada dekat dengan sungai dan menghadap kearah sungai. Banyak kota di dunia yang mengembangkan riverfront guna meningkatkan ekonomi dan lansekap (Follmann, 2015). Riverfront juga dapat memiliki dampak positif untuk mengurangi kontaminasi oleh air (Che, Yang, Chen, \& Xu, 2012; Xu, Wei, Huang, Zhu, \& Li, 2010) Namun konsep ini hanya digunakan untuk permukiman yang berada dekat garis sempadan sungai saja.

\section{Greenhouse}

Konsep greenhouse yaitu konsep yang mengadakan 1 pohon pada setiap rumah dan penghematan energi dengan cara menggunakan panel surya. Konsep greenhouse ini digunakan pada setiap permukiman yang ada di wilayah perencanaan.

3. Permukiman industri

Lalu konsep permukiman industri yaitu permukiman yang berada di dekat dengan kawasan industri, namun permukiman yang dekat dengan kawasan industri tidak akan terganggu karena pada kawasan industri diberi barrier agar tidak mengganggu kenyamanan pada kawasan 
permukiman, dan konsep ini juga hanya digunakan pada kawasan yang berada dekat dengan industri.

\subsubsection{Konsep Pertanian}

Pertanian merupakan komoditas utama yang berada pada wilayah perencanaan. Tentu saja lahan pertanian harus dijaga dan dirawat dengan baik. Maka dari itu konsep pertanian pada wilayah perencanaa ialah tetap mempertahankan dan menjaga lahan pertanian agar tidak terjadi alih fungsi lahan yang berlebihan di masa yang akan datang dan menjaga lingkungan pertanian agar tetap tumbuh.

\subsubsection{Konsep Industri}

Pada kawasan industri di wilayah perencanaan sangat menimbulkan efek yang berdampak pada aspek estetika dan lingkungan. Kegiatan industri tersebut menghasilkan limbah cair dan limbah padat. Limbah-limbah yang dihasilkan dari kegiatan industri tersebut sangat mencemari lingkungan dan nantinya akan berdampak pada lingkungan pertanian. Maka dari itu konsep industri di wilayah perencanaan ialah kawasan industri yang ramah lingkungan dengan mengalirkan limbah-limbah yang dihasilkan menuju ke IPAL agar terkelola dan tidak mencemari lingkungan.

Konsep eco-industrial village membagi ruang hunian berupa rumah ke dalam tiga tipe yakni tipe 36, tipe 54, dan tipe 72 . Hunian tipe 36 akan berada di dekat kawasan industri, hunian tipe 54 akan berada di dekat dan sepanjang sempadan sungai, serta tipe 72 akan berada di dekat main entrance dan jalan kolektor. Pembagian ini didasarkan pada elemen estetika penataan ruang hunian agar dapat membentuk kawasan permukiman yang rapih dan tertata dengan baik.

Konsep ini selain berfokus pada penciptaan industri yang ramah lingkungan juga berfokus pada penghematan energi. Penghematan energi ini dapat direalisasikan melalui penggunaan panel surya. Panel-panel surya ini akan dipasang di setiap atap rumah semua tipe. Begitu pula untuk kawasan industri akan dipasang panel-panel surya di setiap atap pabriknya.

Keberadaan bak sampah di wilayah perencanaan masih kurang dari standar seharusnya. Maka dari itu untuk memenuhi kebutuhan bak sampah pada wilayah perencanaan, maka akan dibangun 12 TPS dengan masing-masing bak sampah memiliki volume 7,5 $\mathrm{m}^{3}$ yang tersebar di setiap dukuh. Pengangkutan sampah akan dilakukan setiap dua kali sehari pada pagi dan sore hari. Setiap bak sampah dibagi menjadi dua bagian yaitu untuk sampah organik dan non organik. Tujuannya agar memudahkan masyarakat melakukan 3R (Reduce, Reuse, Recycle). Bak sampah yang akan dibangun diletakkan jauh dari sungai untuk menghindari terjadinya pencemaran air di sungai tersebut.

Pada setiap cluster kawasan permukiman akan dibangun taman-taman hijau sebagai sarana sosial antar masyarakat. Selain itu pada beberapa bagian sempadan sungai akan dibangun jogging track dan juga kawasan untuk street food lokal. Sepanjang jalan kolektor di wilayah perencanaan akan ditanami vegetasi berupa pohon palm untuk meredam kebisingan dan sebagai penunjuk jalan. Tidak hanya pada sekitar jalan kolektor, namun juga pada area industri. Jenis tanaman yang digunakan sebagai barrier selain dinding pemisah merupakan tanaman yang memiliki daun lebat serta batang pohon yang tinggi. Jenis tanaman atau pohon tersebut adalah glodokan tiang. Pada pinggir jalan menuju kawasan industri menggunakan pohon palm, pada sepanjang pinggiran sungai menggunakan pohon akasia dan pohon rimbun lainnya.

\subsection{Indikator Konsep}

Berikut ini merupakan indikator-indikator konsep eco industrial village yang akan diterapkan pada wilayah perencanaan.

a. Tautan Wilayah

Kecamatan Tulung menurut arahan Rencana Tata Ruang Wilayah termasuk dalam wilayah pusat kegiatan industri, agropolitan, dan minapolitan. Aktivitas yang terdapat di wilayah perencanaan antara lain aktivitas hunian, pertanian, dan industri. 


\section{b. Topografi}

Berdasarkan hasil analisis, topografi landai seperti yang terdapat pada wilayah perencanaan cocok digunakan untuk berbagai macam fungsi lahan, khususnya lahan terbangun seperti permukiman, perdagangan dan jasa, serta aktivitas penunjang lainnya.

\section{c. Drainase}

Drainase di kawasan permukiman tetap menggunakan drainase tersier terbuka dan tertutup. Drainase di jalan kolektor akan dibuat drainase saluran primer yang akan membawa air ke sungai.

\section{d. Aksesibilitas}

Jalan kolektor dan jalan lokal di lokasi perencanaan belum memenuhi standar. Maka akan dilakukan pelebaran jalan sesuai proyeksi pengguna pada tahun 2039 dan standar yang berlaku. Nantinya akan dibangun 2 ruas jalan baru agar aksesibilitas pada wilayah perencanaan lebih baik. Jalan baru berguna untuk memudahkan akses industri dengan jalan kolektor. Kemudahan yang dimaksud yaitu proses distribusi barang mentah dan barang hasil produksi dapat disalurkan secara lebih efektif karena akses yang mudah.

\section{e. Kebisingan}

Kawasan yang memiliki tingkat kebisingan tinggi berada di sekitar jalan kolektor. Pada jalan kolektor akan diberi barrier berupa pohon palm untuk mengurangi tingkat kebisingannya. Kawasan dengan tingkat kebisingan rendah cocok untuk kawasan permukiman yang tersebar dan berada jauh dari jalan kolektor. Pada kawasan industri karena memiliki tingkat kebisingan sedang maka akan diberikan barrier juga berupa tembok untuk mengurangi kebisingannya.

f. View

Konsep pemukiman di wilayah perencanaan terbagi menjadi tiga konsep yaitu riverfront view, greenhouse, dan permukiman industri. Untuk merespon good view dan bad view maka akan dibuat respon dengan view from site dan view to site.

- View from site

Untuk kawasan permukiman yang menerapkan konsep greenhouse yaitu tipe hunian 36, 54, dan 72 akan dibuat menghadap ke area persawahan yang dijadikan sebagai acuan good view. Untuk permukiman yang menghadap ke sungai akan menggunakan konsep riverfront yang nantinya pada sepanjang garis sempadan sungai akan dibuatkan jogging track dan taman.

\section{- View to site}

Untuk permukiman yang berada dekat dengan kawasan industri, agar dapt mengurangi bad view di kawasan tersebut maka akan dibuat barrier berupa tembok sebagai pembatas antara kawasan industri dengan permukiman.

\section{g. Lintasan Matahari dan Angin}

Orientasi bangunan terhadap arah matahari diarahkan dari arah timur ke barat. Orientasi bangunan terhadap arah angin dengan melihat jarak bangunan dan penempatan bukaan untuk sirkulasinya agar mengurangi penggunaan AC. Untuk memperlambat arah angin dan mengurangi panas matahari, maka akan diletakkan pohon di depan rumah. Pintu dan jendela disesuaikan menghadap matahari terbit.

h. Vegetasi

Vegetasi diletakkan pada sekitar Jalan Kolektor Jatinom-Boyolali sebagai penunjuk jalan dan untuk meredam kebisingan yang diakibatkan oleh kendaraan. Jenis pohon yang digunakan adalah jenis pohon palm. Tidak hanya pada sekitar jalan kolektor, namun juga pada area industri. Jenis tanaman yang digunakan sebagai barrier merupakan tanaman yang memiliki daun lebat serta batang pohon yang tinggi. Jenis tanaman atau pohon tersebut adalah glodokan tiang. Pada pinggir jalan menuju kawasan industri menggunakan pohon palm, pada sepanjang pinggiran sungai menggunakan pohon akasia dan pohon rimbun lainnya.

i. Tata Masa Bangunan

Orientasi bangunan lebih baik menghadap ke arah utara / selatan untuk pintu dan ventilasi/bukaan. Bukaan seperti jendela diletakkan di bagian timur rumah. Orientasi bangunan yang mengarah ke timur atau barat, pada bagian bukaannya akan diberikan barrier sinar matahari dan angin berupa pepohonan agar paparan sinar matahari tidak langsung menyinari ke dalam rumah penduduk. Pada wilayah perencanaan direncanakan dibangun tiga tipe hunian, antara lain hunian tipe 36 , tipe 54 , dan tipe 72 . Tipe 72 berada di dekat main entrance, tipe 54 
berada di sekitar sempadan sungai, dan tipe 36 berada di dekat kawasan industri dan tersebar di cluster-cluster lainnya.

j. Sistem Jaringan Jalan

Berdasarkan hasil analisis, direncanakan akan dibangun pola jaringan jalan seperti pada hasil analisis aksesibilitas. Selain itu, direncanakan akan dilakukan peningkatan dan pelebaran pada ruang jalan kolektor menjadi 4 lajur 2 jalur atau 4/2 T. Jalan kolektor direncanakan akan memiliki lebar 15 meter yang terbagi atas jalan efektif, pembatas jalan dan trotoar.

Pelebaran dilakukan karena lebar jalan eksisting, tidak sesuai standar dan arus lalu lintas yang mulai padat akibat kapasistas jalan semakin menurun. Tujuan lain yaitu untuk meningkatkan aksesibilitas wilayah perencanaan terhadap wilayah lain ataupun sebaliknya. Penambahan pemisahan arah jalur didasarkan atas mobilisasi yang semakin tinggi sehingga dibutuhkan kejelasan pemisahan jalur. Selain itu pula ditambahkan trotoar untuk menekan hambatan samping pada ruas jalan.

Ruas jalan lokal akan dilakukan pelebaran menjadi 10 meter dengan 2 lajur dan 2 jalur tak terbagi atau 2/2 TT. Bertujuan untuk mendukung mobilisasi pada wilayah perencanaan agar aksesibilitas kawasan lebih baik. Ruas jalan lingkungan akan dilakukan pelebaran menjadi5 meter dengan 2 lajur 2 jalur tak terbagi atau 2/2 TT. Selain untuk pemenuhan standar, pelebaran juga bertujuan untuk memudahkan akses mobil pemadam kebakaran agar dapat memasuki lingkungan permukiman sebagai upaya pencegahan jika terjadi kebakaran.

k. Sistem Jaringan Listrik

Jaringan listrik akan dibuat di bawah tanah mengikuti jaringan jalan agar tidak merusak estetika. Kawasan setiap 100 meter akan terdapat lubang bukaan yang digunakan untuk maintenance dari jaringan listrik. Untuk hunian, listrik menggunakan listrik yang bersumber dari PLN dan tenaga surya. Pemakaian panel surya di wilayah perencanaan diasumsikan sebagai berikut:

Untuk 1 panel surya menampung daya sebesar 100 watt dengan dimensi 1005 x 668 x $30 \mathrm{~mm}$.

1. Tipe $36=450 \mathrm{watt} ; 5 \mathrm{panel} / \mathrm{rumah} \times 530$ bangunan $=2650$ unit

2. Tipe $54=720 \mathrm{watt} ; 8 \mathrm{panel} / \mathrm{rumah} \times 535$ bangunan $=4280$ unit

3. Tipe $72=1040$ watt; 11 panel/rumah $\times 177$ bangunan $=1947$ unit

Jadi, untuk kebutuhan keseluruhan panel surya adalah sebanyak 8877 unit.

1. Sistem Jaringan Air Bersih

Konsep sistem pengelolaan air bersih pada wilayah perencanaan yaitu direncanakan dengan membuat PAMSIMAS (Penyedia Air Minum dan Sanitasi Berbasis Masyarakat) untuk memenuhi kebutuhan air bersih penduduk. PAMSIMAS memiliki debit air lebih dari 119.451,67 L/hari. Jaringan pipa air bersih mengikuti jaringan jalan. PAMSIMAS diletakkan pada kawasan industri karena kebutuhan air di kawasan industri dan sekitarnya lebih tinggi kebutuhan air pada kawasan permukiman. Sedangkan pada kawasan permukiman dikonsepkan menggunakan PAMSIMAS dari air sumur.

m. Sistem Jaringan Drainase

Upaya yang dapat dilakukan untuk mengurangi aliran air yang meluap ke jalan adalah dengan memperbanyak drainase dengan sistem tertutup. Drainase yang tertutupi beton yang bisa terangkat agar sampah tidak masuk dalam drainase dan mudah dipantau sewaktu-waktu.

n. Sistem Jaringan Sanitasi

Total limbah pada wilayah perencanaan tahun 2039 yaitu (jumlah limbah greywater + jumlah limbah blackwater $)=376.816,86+8484=385.300,86$ L/hari. Dibutuhkan sistem IPAL untuk menampung limbah tersebut. Wilayah perencanaan menggunakan saluran off-site. Timbulan air limbah rumah tangga disalurkan menggunakan sistem jaringan perpipaan off-site. Kemudian diolah melalui sistem IPAL. Namun sistem IPAL ini berada di luar deliniasi wilayah perencanaan.

o. Sistem Jaringan Pemadam Kebakaran

Konsep sistem penanganan bencana kebakaran pada wilayah perencanaan yaitu dengan membuat akses jalan lingkungan yang dapat dilalui oleh mobil pemadam kebakaran. Mobil pemadam kebakaran ini memiliki lebar 2 meter dan panjang 4 meter. Direncanakan mobil 
pemadam kebakaran dapat melalui semua jalan lingkungan yang ada di wilayah perencanaan dengan lebar akses jalan selebar 4 meter.

p. Sistem Jaringan Sampah

Untuk memenuhi kebutuhan bak sampah pada wilayah perencanaan, maka akan dibangun 12 TPS dengan masing-masing bak sampah memiliki volume $7,5 \mathrm{~m}^{3}$ yang tersebar di setiap dukuh. Pengangkutan sampah akan dilakukan setiap dua kali sehari pada pagi dan sore hari. Setiap bak sapah dibagi menjadi dua bagian yaitu untuk sampah organik dan non organik. Tujuannya agar memudahkan masyarakat melakukan 3R (Reduce, Reuse, Recycle). Bak sampah yang akan dibangun diletakkan jauh dari sungai untuk menghindari terjadinya pencemaran air di sungai tersebut.

\section{q. Sistem Jaringan Telekomunikasi}

Berdasarkan hasil analisis, didapatkan hasil bahwa dibutuhkan 3 BTS lagi untuk dapat melayani pengguna seluler hingga 20 tahun mendatang. Nantinya akan ada sebanyak 4 BTS. Keempat BTS ini akan diletakkan menyebar di wilayah perencanaan untuk memperluas radius pelayanannya.

\subsection{Zoning}

Berdasarkan Gambar 3 kawasan perencaan dibagi ke dalam dua jenis ruang yakni ruang publik dan ruang privat. Ruang publik meliputi kawasan perdagangan dan jasa, industri, serta pertanian berupa sawah, sedangkan ruang privat berupa permukiman. Zona perdagangan dan jasa diletakkan di sekitar jalan utama sebab jalan tersebut akan banyak dilalui orang. Zona permukiman direncanakan tidak memusat sebab konsep pertanian pada perencanaan wilayah ini adalah menghindari adanya alih fungsi. Dengan demikian, pertanian-pertanian pada kawasan tersebut mempertahankan kondisi eksistingnya

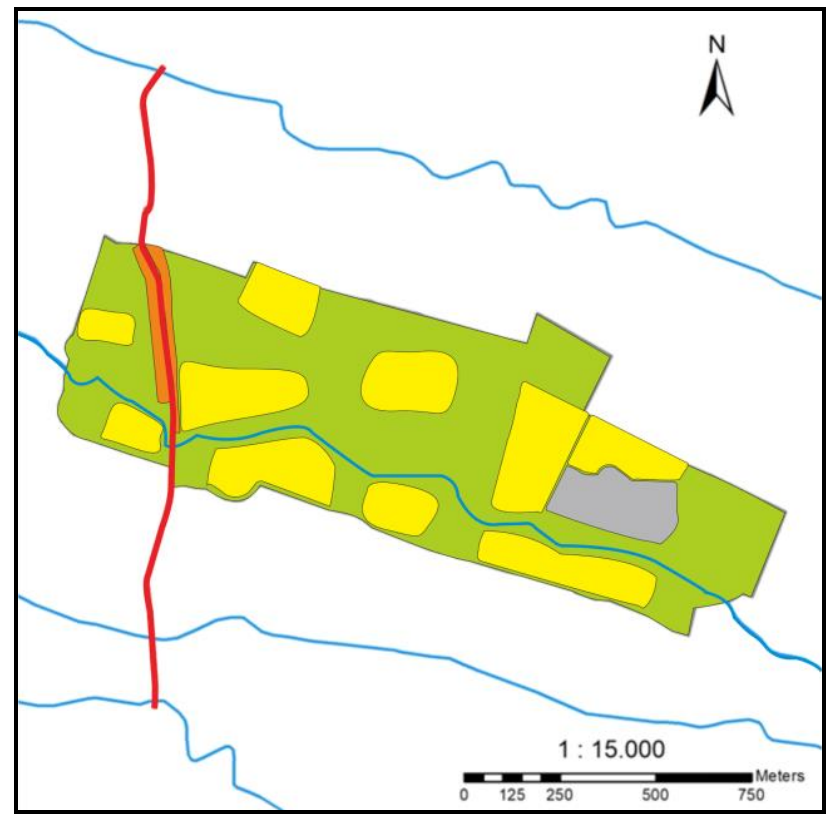

Gambar 3. Zonasi Kawasan Perencanaan (Analisis Penulis, 2019)

Keterangan :

\section{Ruang Publik}

Zona Perdagangan dan Jasa

Zona perdagangan dan jasa ini diletakkan di sekitar jalan utama yang meliputi kios
Sawah

Mempertahankan dan menjaga lahan pertanian agar tidak terjadi alih fungsi lahan yang berlebihan di masa yang akan datang dan menjaga lingkungan pertanian agar tetap tumbuh. 


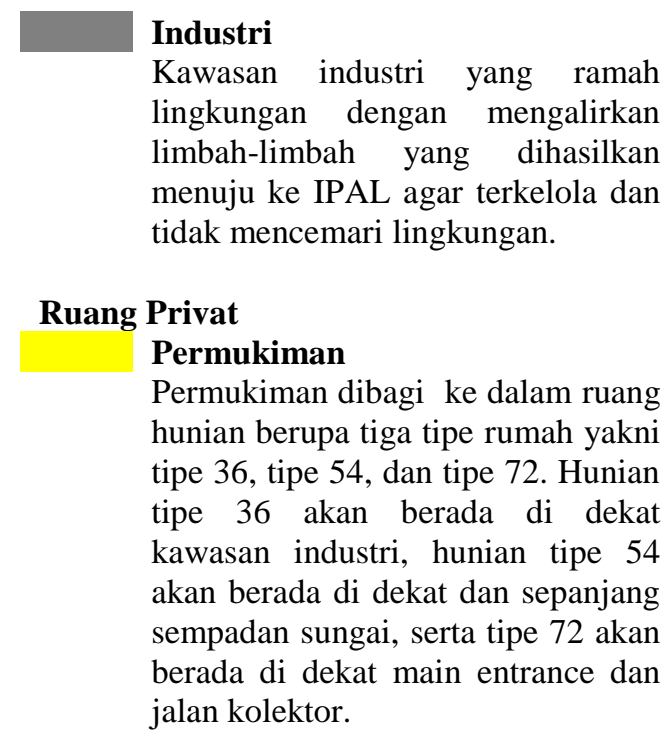

\section{Kesimpulan}

Wilayah penelitian ini termasuk ke dalam Kecamatan Tulung yang meliputi Desa Tulung, Desa Pucang Miliran, dan Desa Daleman. Lahan di wilayah studi dipergunakan untuk permukiman, pertanian, serta industri berupa industri mie soun. Kawasan permukiman di wilayah studi berdampingan dengan kawasan industri yang berpotensi menimbulkan potensi dan masalah. Terutama permasalahan yang berkaitan dengan lingkungan, seperti pencemaran limbah. Disisi lain, industri yang terdapat di wilayah studi juga berpotensi untuk meningkatkan kesejahteraan masyarakat sekitarnya. Konsep pengembangan wilayah yang sesuai untuk menyiasati kondisi tersebut adalah eco-industrial village. Konsep eco-industrial village memfokuskan pada perencanaan kawasan permukiman yang sehat, aman, dan nyaman untuk ditinggali meskipun harus berdampingan dengan kawasan industri yang bising. Konsep eco industrial village dirincikan lagi berdasarkan peruntukkan kebutuhan dari aktivitas penduduknya, yakni konsep permukiman, konsep industri, dan konsep pertanian.

\section{Referensi}

Adalilar, S. N., Alkibay, S., \& Eser, Z. (2015). Ecovillages as a Destination and a Study of Consumer Approaches to Ecovillages. Procedia Economics and Finance, 23(October 2014), 539-546. https://doi.org/10.1016/s2212-5671(15)00561-4

Che, Y., Yang, K., Chen, T., \& Xu, Q. (2012). Assessing a riverfront rehabilitation project using the comprehensive index of public accessibility. Ecological Engineering, 40, 80-87. https://doi.org/10.1016/j.ecoleng.2011.12.008

Follmann, A. (2015). Urban mega-projects for a "world-class" riverfront - The interplay of informality, flexibility and exceptionality along the Yamuna in Delhi, India. Habitat International, 45(P3), 213222. https://doi.org/10.1016/j.habitatint.2014.02.007

Hall, R. (2015). The ecovillage experience as an evidence base for national wellbeing strategies. Intellectual Economics, 9(1), 30-42. https://doi.org/10.1016/j.intele.2015.07.001

Jackson, H. (1998). What is an Ecovillage. In Gaia Trust Education Seminar (Vol. 204).

Koestoer, R. H. (1997). Perspektif lingkungan desa-kota: teori dan kasus. Penerbit Universitas Indonesia.

Ristianti, N. S. (2016). S.M.A.R.T. Eco-village for Hazardous Coastal Area in Bedono Village, Demak Regency. Procedia - Social and Behavioral Sciences, 227(November 2015), 593-600. https://doi.org/10.1016/j.sbspro.2016.06.120

Roysen, R., \& Mertens, F. (2019). New normalities in grassroots innovations: The reconfiguration and normalization of social practices in an ecovillage. Journal of Cleaner Production, 236, 117647. https://doi.org/10.1016/j.jclepro.2019.117647

Sherry, J. (2019). The impact of community sustainability: A life cycle assessment of three ecovillages. Journal of Cleaner Production, 237, 117830. https://doi.org/10.1016/j.jclepro.2019.117830

Xu, J., Wei, Q., Huang, X., Zhu, X., \& Li, G. (2010). Evaluation of human thermal comfort near urban waterbody during summer. Building and Environment, 45(4), 1072-1080. https://doi.org/10.1016/j.buildenv.2009.10.025 